\title{
THE CHALLENGES OF GEOTECHNICAL EXPLORATION IN BANGLADESH FOR SUSTAINABLE URBAN DEVELOPMENT AND RISK REDUCTIONS IN ENGINEERING GEOLOGY
}

\author{
Mir Fazlul Karim \\ Geocomp Corporation / GeoTesting Express Inc., USA \\ (Former Director, Geological Survey of Bangladesh), \\ Nazrul I. Khandaker \\ Earth and Physical Sciences, York College (CUNY), USA \\ Muhammad Qumrul Hassan \\ Department of Geology, University of Dhaka, Dhaka, 1000, Bangladesh \\ and
}

A.T.M. Shakhawat Hossain

Department of Geological Sciences, Jahangirnagar University, Dhaka, 1342, Bangladesh

Contacting Author

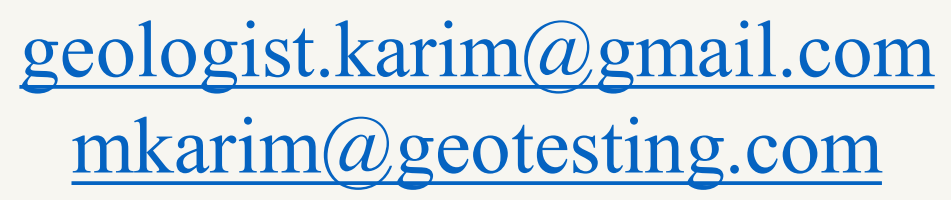


GSA Annual Meeting in Indianapolis, Indiana, USA - 2018

Paper No. 2-5 Presentation Time: 9:15 AM

\section{THE CHALLENGES OF GEOTECHNICAL EXPLORATION IN BANGLADESH FOR SUSTAINABLE URBAN DEVELOPMENT AND RISK REDUCTIONS IN ENGINEERING GEOLOGY}

KARIM, Mir F., Geocomp Corporation, Geotesting Express Inc., 125, Nagog Park, Acton, MA 01720, KHANDAKER, Nazrul I., Earth and Physical Sciences, York College (CUNY), Geology Discipline, AC-2F09, 94-20 Guy R. Brewer Blvd, Jamaica, NY 11451, HASSAN, Muhammad Qumrul, Department of Geology, University of Dhaka, Dhaka, 1000, Bangladesh and HOSSAIN, A.T.M. Shakhawat, Geological Engineering and Geohazards Group, Department of Geological Sciences, Jahangirnagar University, Savar, Dhaka, 1342, Bangladesh

\section{ABSTRACT}

Bangladesh is a unique example of rapid urbanization where the urban population increased from 5 to 58 million in last four decades. Due to complex geology and active tectonic setting, the urban ground is impacted by fluvio-deltaic processes and regional seismicity. The densely populated cities of the country are facing risks from many natural hazards like floods, tidal surge, riverbank and coastal erosion, scour, landslides, soil collapse and foundation failures. Geologists anticipate severe seismic threats from yet-undefined tectonic structures and seek to determine their consequential geo-structural responses and conformance to the national building code. With rapid growth, demands on infrastructure have driven the need for better understanding of geotechnical exploration and geologic factors that will contribute to a more manageable, livable, resilient and sustainable infrastructure. The relationship of geo-hazards, geotechnical exploration methods and engineering geologic practices are discussed here. The study indicates that geotechnical exploration method, reporting and laboratory testing practices in current use have yet to adopt standard and quality control techniques. Engineering geology is concerned with subsurface construction, operation and maintenance for safe and sustainable structures. Modified large-scale (1:5000) engineering geologic maps are prepared for selected parts of Dhaka to evaluate and integrate the geologic hazards and engineering geologic risk. Because of unplanned urban expansion, many cities of Bangladesh will require intense modification to the exiting infrastructures including effective utilization of underground space and construction of multilevel transportation system. Risk is always present in any alteration of geologic environment during and after construction. Although the underlying thick hard clay and very dense sand in Dhaka provide advantageous ground condition comparing to other cities of the world, the country is confronting difficult geo-engineering challenges for sustainable development and needs to have standardized geotechnical exploration methods, updated geologic maps and improved laboratory testing system to accurately characterize geologic materials for modeling to meet challenges of sustainable development and risk reduction.

Session No. 2 T18. Generating Sustainable Urban Systems: A Convergence of Geology and Society Sunday, 4 November 2018: 8:00 AM-12:00 PM Room 135 (Indiana Convention Center). Geological Society of America Abstracts with Programs. Vol. 50, No. 6 doi: 10.1130/abs/2018AM-321408 


\section{Bangladesh is a unique example of rapid urbanization where the urban population increased from 5 to 58 million in last four decades.}

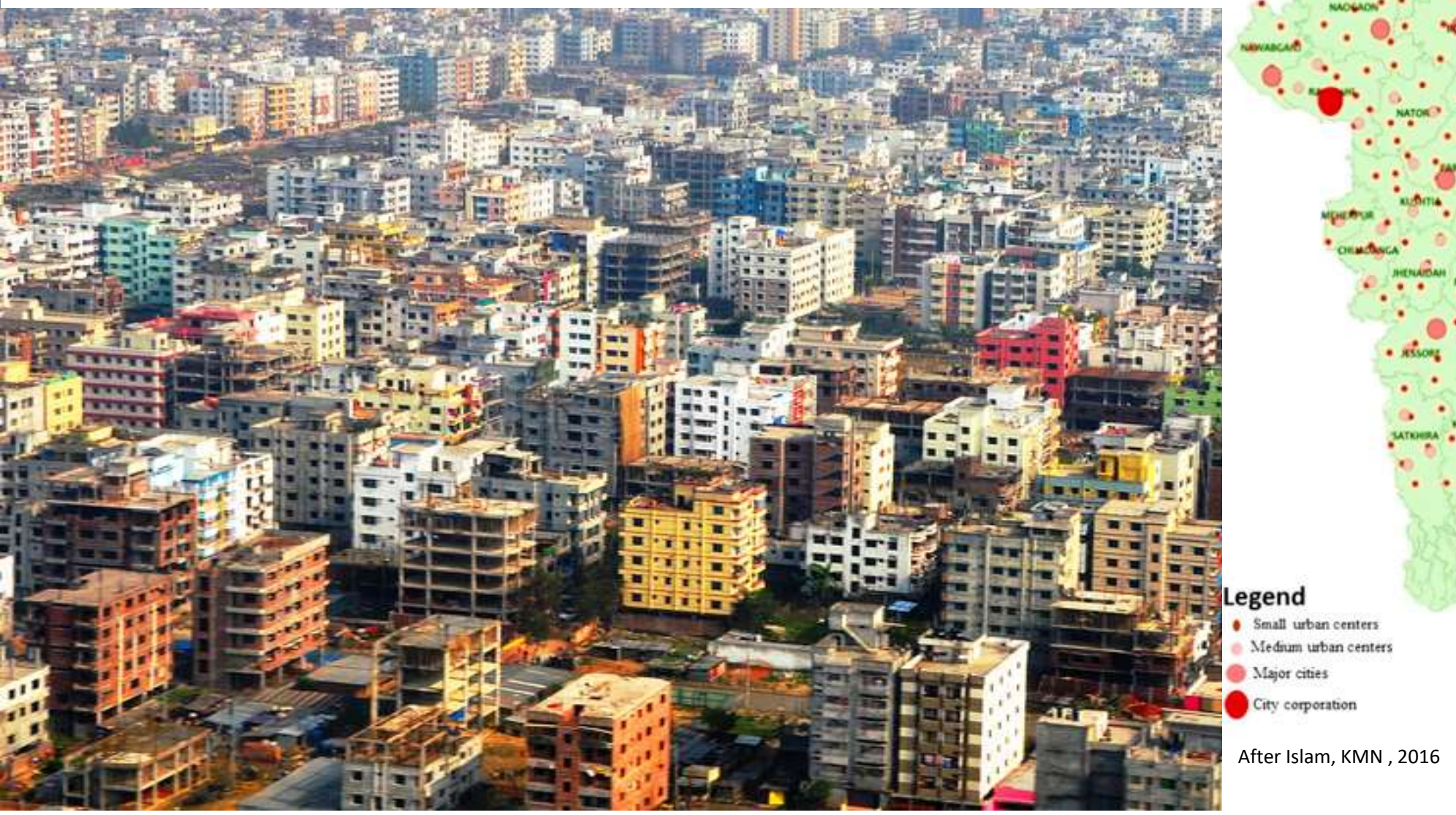

Bangladesh urban centers

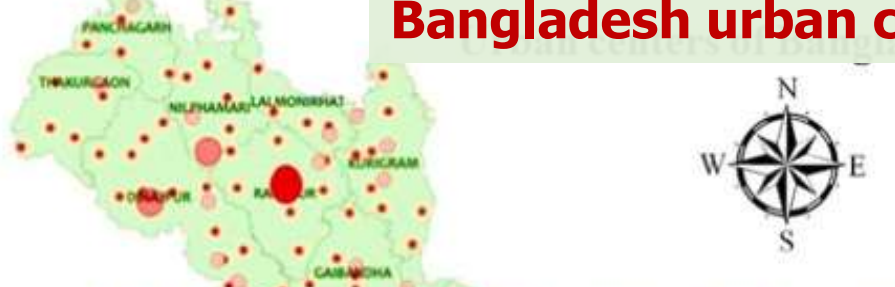




\section{Rapid chronological expansion of urban area: Case Dhaka Megacity}

Today Dhaka is one of the 20 Mega cities of the world having population of $19,580,000$, ranking $10^{\text {th }}$ in the world.

Urbanization in Bengal started during the Kingdom of Kamarupa between 350 and 1140 CE. The city of Dhaka achieved importance during Sultanate Period in $16^{\text {th }}$ Century and became capital of Bengal during Mughal rule, flourished during British East India Company rule (1772-1857) and British Raj (1858-1947).

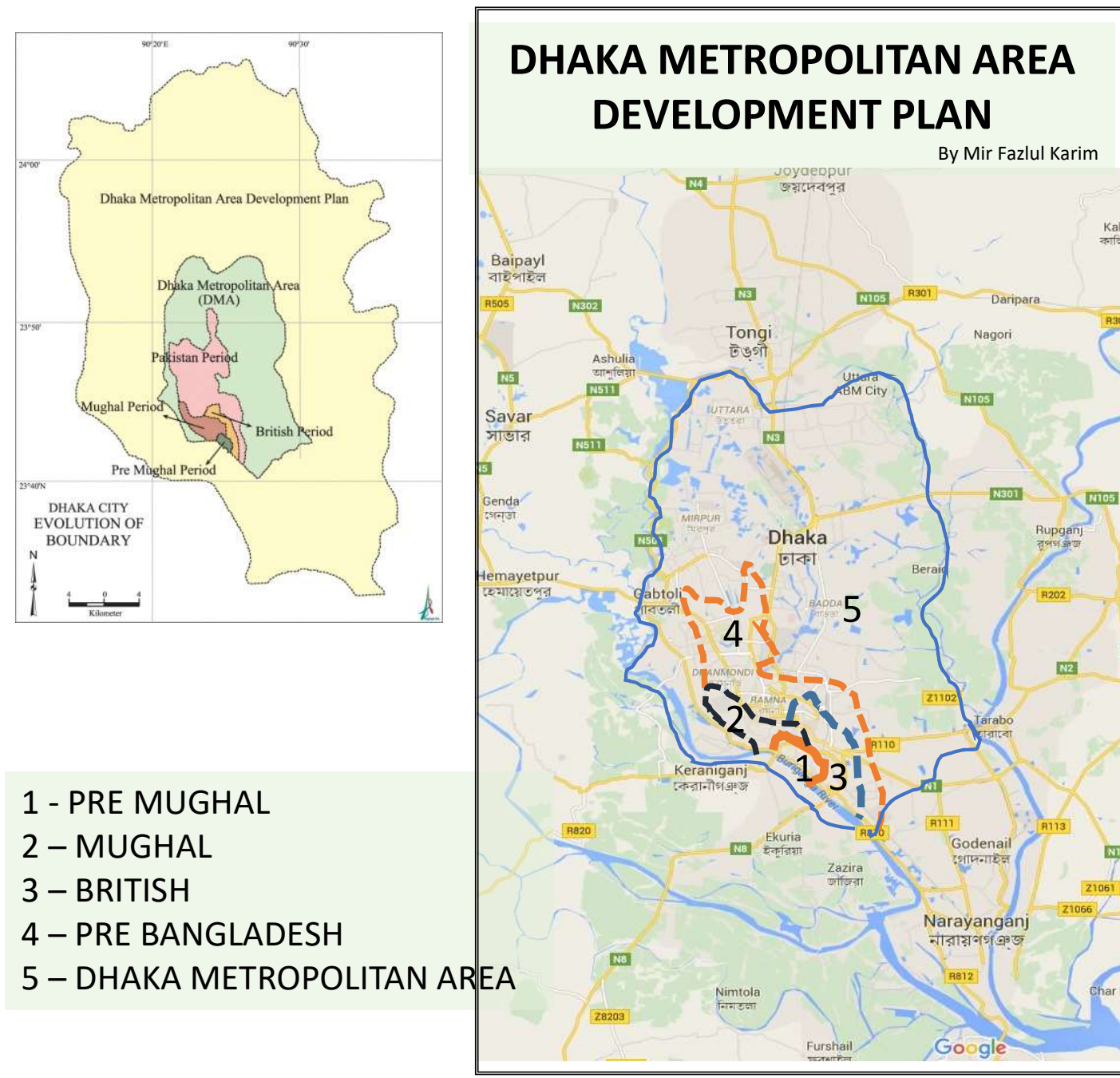




\section{PEOPLE ARE RUSHING TO URBAN ENVIRONMENT}
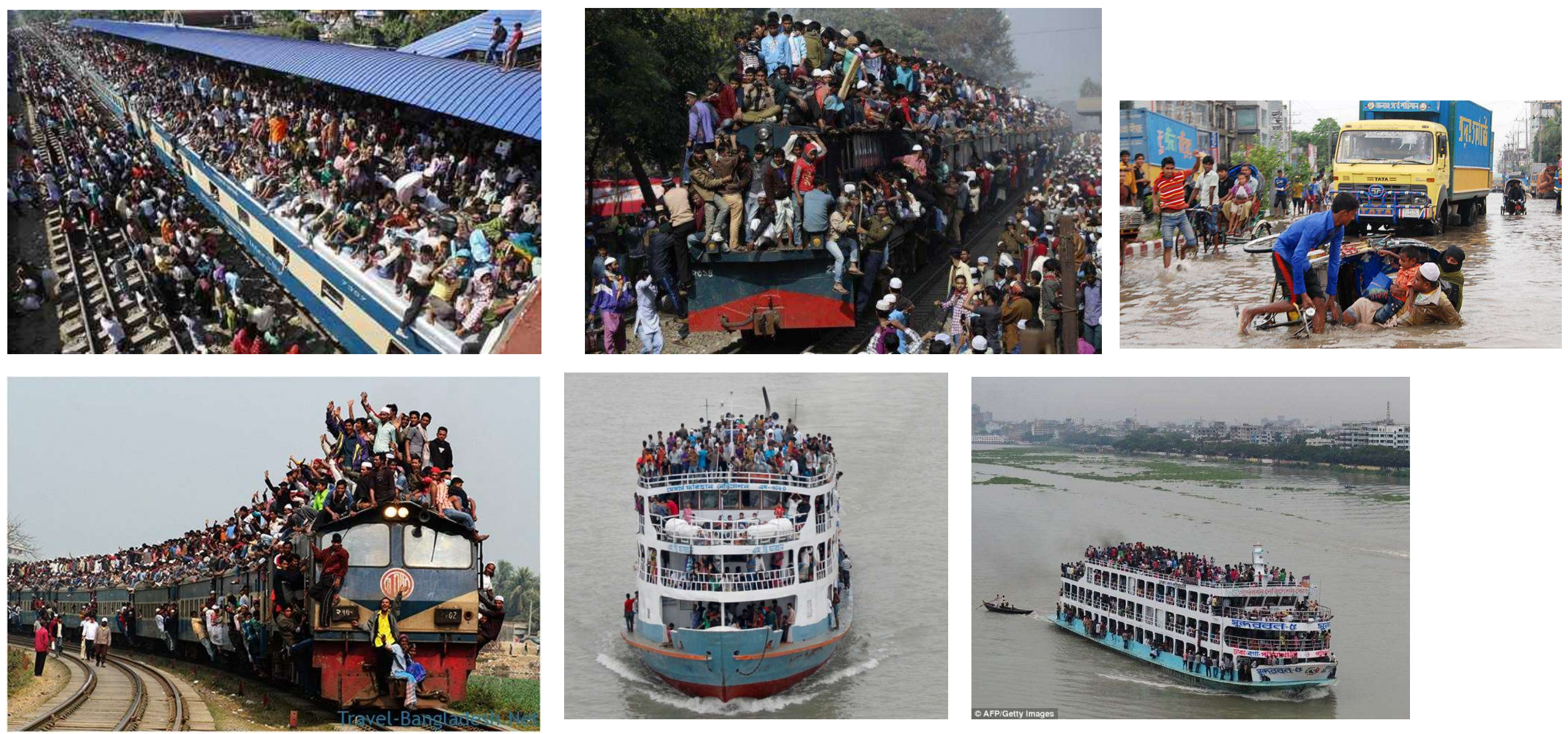


\section{AFFECT OF UNPLANNED URBAN GROWTH}
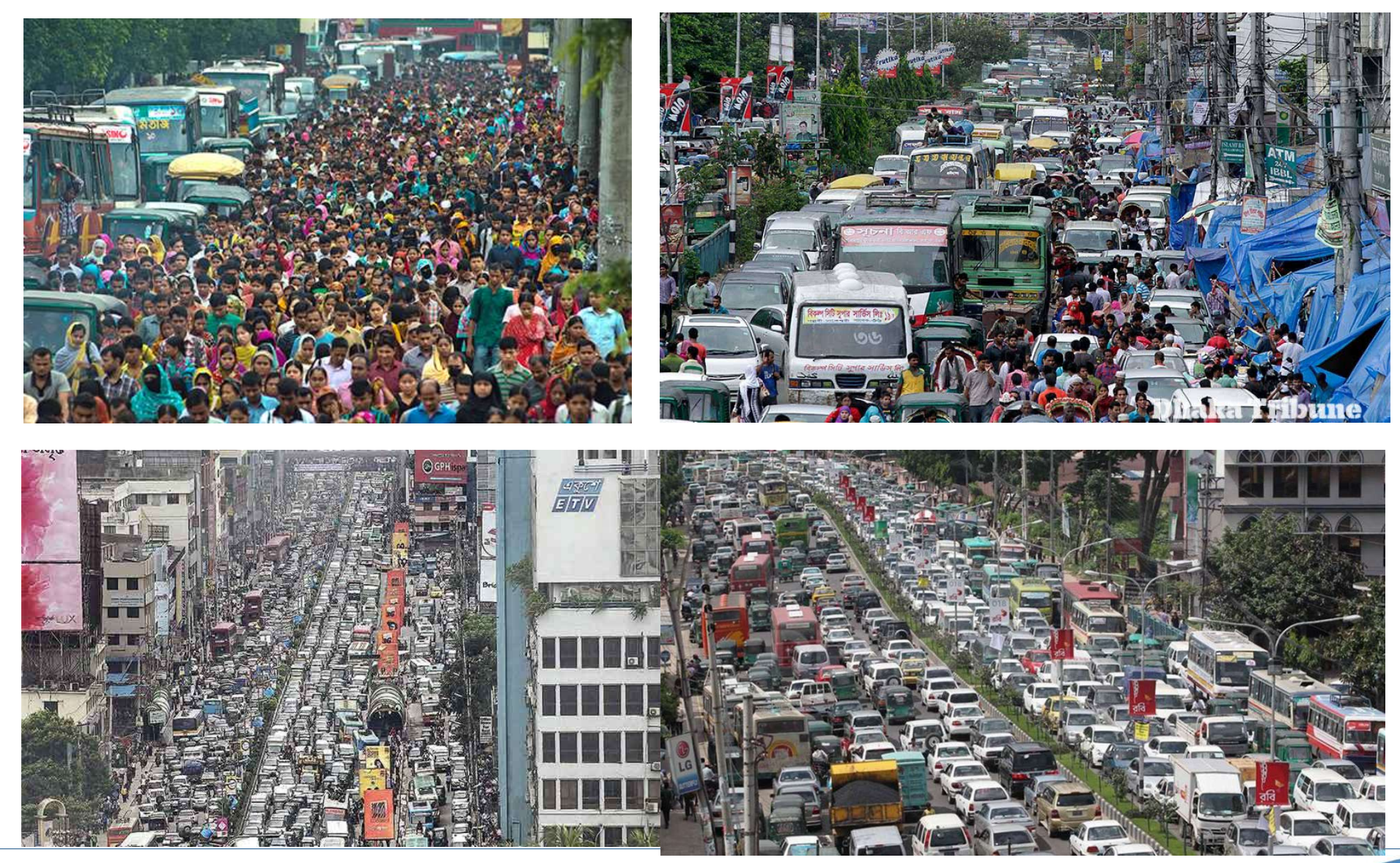
Geology of Bangladesh and the associated challenging hazards vs geological environment

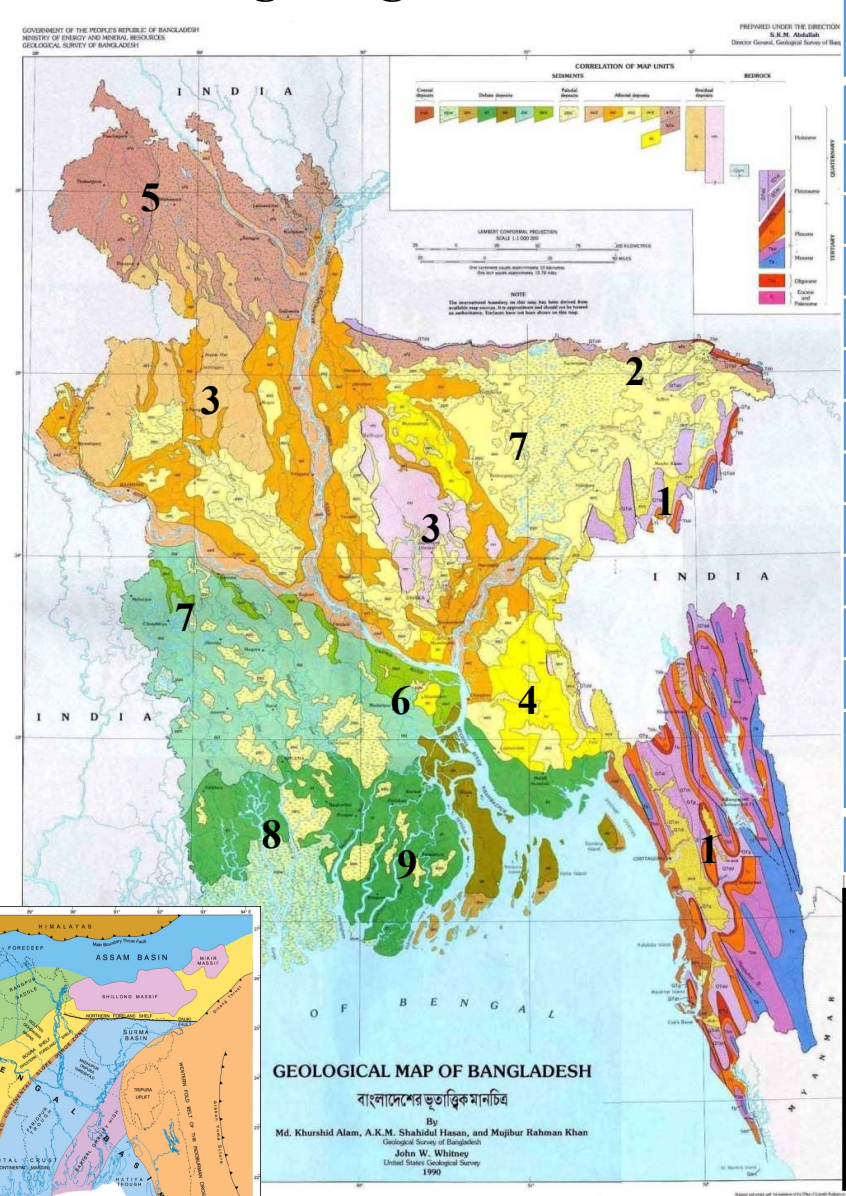

\begin{tabular}{|c|c|c|c|c|c|c|}
\hline \multirow[b]{2}{*}{$\begin{array}{c}\text { Visible } \\
\text { Geological } \\
\text { Hazards }\end{array}$} & \multicolumn{6}{|c|}{ Geological Environment } \\
\hline & $\begin{array}{c}\text { Fluvial/ } \\
\text { Piedmont } \\
\text { plain }\end{array}$ & $\begin{array}{l}\text { Flood } \\
\text { plain }\end{array}$ & $\begin{array}{l}\text { Coastal } \\
\text { plain }\end{array}$ & Terrace & Hills & Valleys \\
\hline River bank erosion & $Y$ & Y & Y & $\mathrm{N}$ & $\mathrm{N}$ & $\mathrm{N}$ \\
\hline Scour & Y & Y & Y & $\mathrm{N}$ & $\mathrm{N}$ & Y \\
\hline Soil erosion & $Y$ & Y & Y & Y & $Y$ & $\mathrm{~N}$ \\
\hline Earthquake & Y & Y & Y & Y & Y & Y \\
\hline Debris flow & $\mathrm{N}$ & $\mathrm{N}$ & $\mathrm{N}$ & Y & $\mathrm{Y}$ & Y \\
\hline Slope failure & $\mathrm{N}$ & $\mathrm{N}$ & $\mathrm{N}$ & Y & Y & Y \\
\hline Sand flow & $\mathrm{Y}$ & Y & $\mathrm{N}$ & $\mathrm{N}$ & Y & Y \\
\hline Subsidence & $\mathrm{N}$ & Y & Y & $\mathrm{N}$ & $\mathrm{N}$ & $\mathrm{N}$ \\
\hline Swelling soil & $\mathrm{N}$ & $\mathrm{N}$ & $\mathrm{N}$ & Y & $\mathrm{Y}$ & Y \\
\hline Water logging & $\mathrm{N}$ & Y & $Y$ & $Y$ & $Y$ & $Y$ \\
\hline Flash flood & $Y$ & $\mathrm{~N}$ & $\mathrm{~N}$ & $Y$ & $Y$ & $Y$ \\
\hline Annual flood & $\mathrm{N}$ & $Y$ & Y & $Y$ & $\mathrm{~N}$ & $\mathrm{~N}$ \\
\hline $\begin{array}{c}\text { Saline water } \\
\text { intrusion }\end{array}$ & $\mathrm{N}$ & $\mathrm{N}$ & $Y$ & $\mathrm{~N}$ & $\mathrm{~N}$ & $\mathrm{~N}$ \\
\hline Tidal flood & $\mathrm{N}$ & $Y$ & $Y$ & $\mathrm{~N}$ & $\mathrm{~N}$ & $\mathrm{~N}$ \\
\hline
\end{tabular}

Geological Units : 1 and 2 - Folded hills of Tertiary sedimentary rock

3 - Pleistocene Terraces Barind and Madhupur, 4 - Old Alluvial Deposit (Chandina Alluvium),

5 - Alluvial Fan Deposit, 6 - Paludal Deposit, Marshy clay \& peat

7 - Young Alluvial Deposit (Inter-stream deposit), 8 and 9 - Deltaic and Coastal Deposit. Including Beach, Estuarine and Mangrove swamp deposits. 
Due to complex geology and active tectonic setting, the urban ground is impacted by fluvio-deltaic processes and regional seismicity. Geology is the key factor of all natural hazards and risks. Consistent to physical distribution
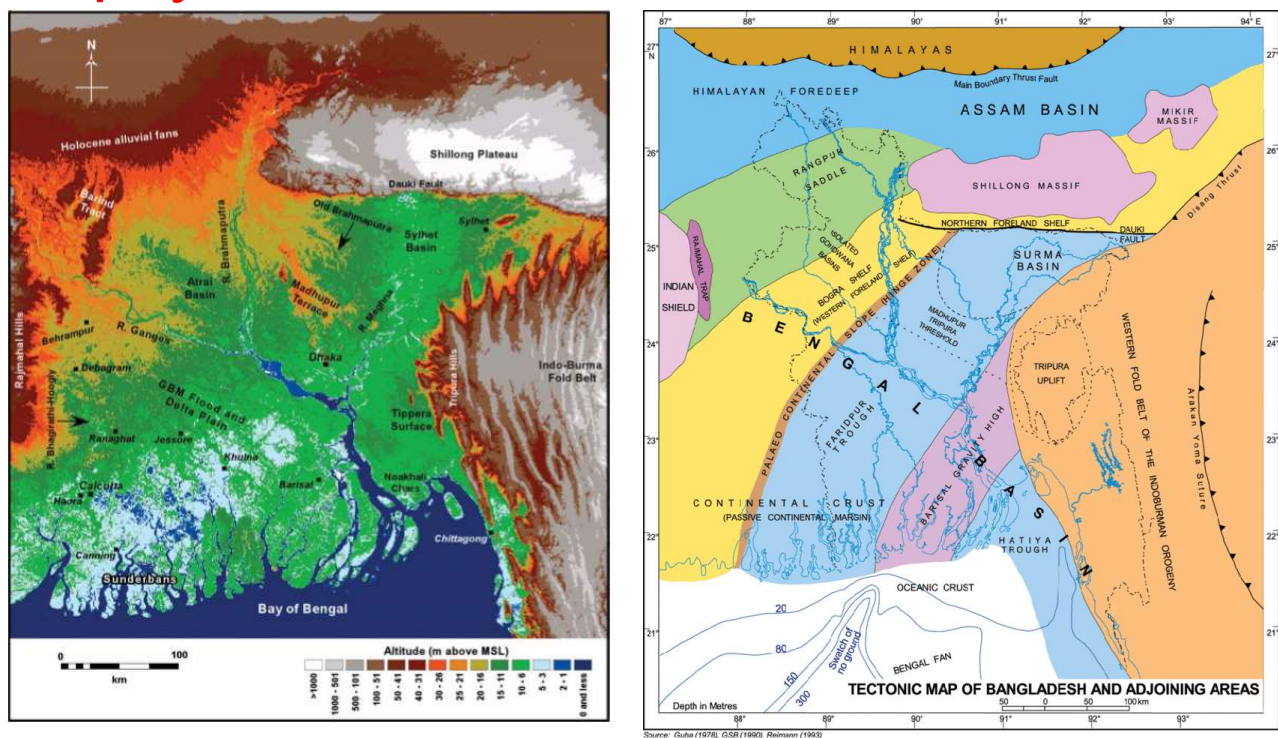

Geomorphic map of the Bengal basin super imposed on the Shuttle Radar Topography Mission (SRTM) DEM distinguishing different geological features and cities, and consistent to the tectonic map of Bangladesh prepared by Geological Survey of Bangladesh.

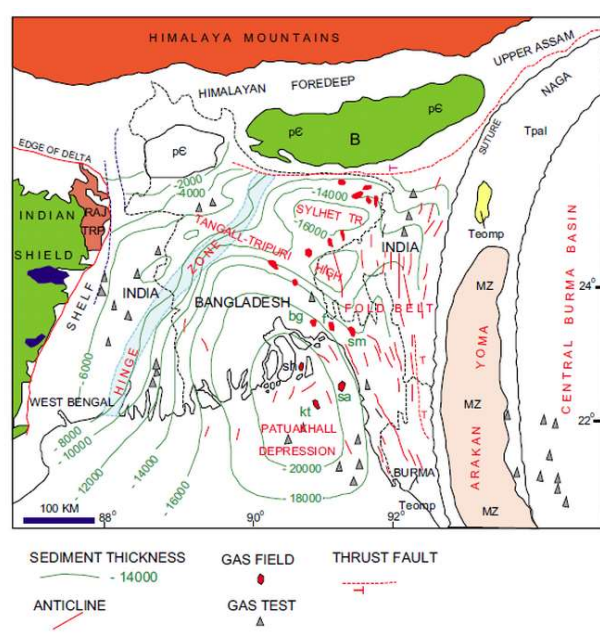

Hiller, K. and Elahi, M. (1984) Structural development and hydrocarbon entrapment in the Surma Basin, Bangladesh (northwest IndoSouthwest Conference pp.656-663.

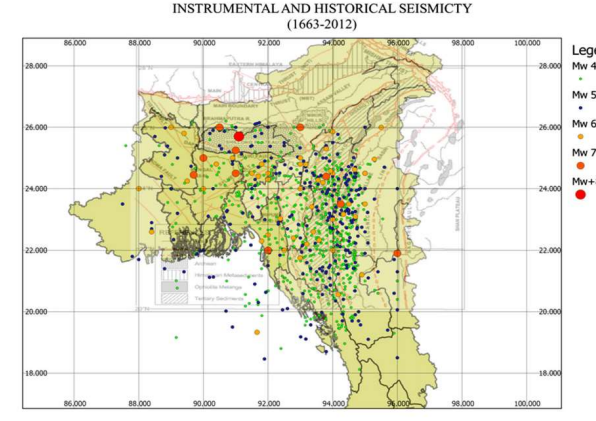

Fig. 4 Compositc carhhuake catalogue
Probabilistic seismic hazard analysis at a strategic site in the Bay of Bengal, By Sara Cristina Teresa Trianni • Carlo Giovann Lai • Erio Pasqualini, Springr, 14 June, 2014

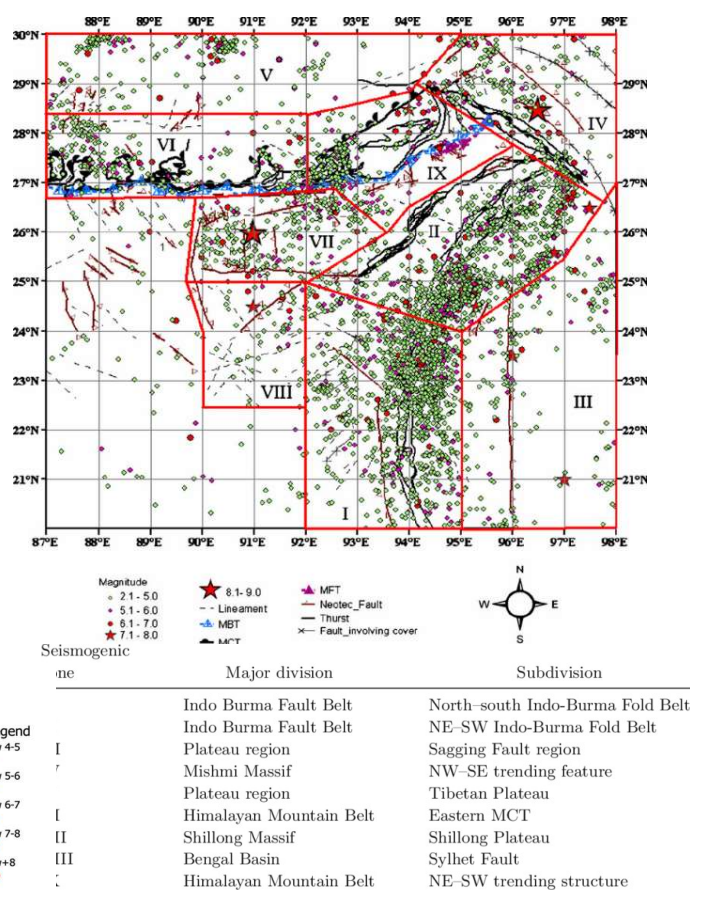

Ranjit Das et al

Temporal and spatial variations in the magnitude of completeness for homogenized moment magnitude catalogue for northeast India, Journal of Earth System Science 121(1):19$28 \cdot$ September 2011 


\section{Dynamic Convergence of Geology and Society}

(In fact society is not aware of the geology under their feet. Geologists need to identify and disseminate the real status of engineering geology.)

\section{WHY IT IS SO NECESSARY? Let's see next..}




\section{A paradigm shift in tectonic configuration of Bengal Basin}

Recently geologists anticipate severe seismic threats from yet-undefined tectonic structures and seek to determine their consequential geo-structural responses and conformance to the national building code.
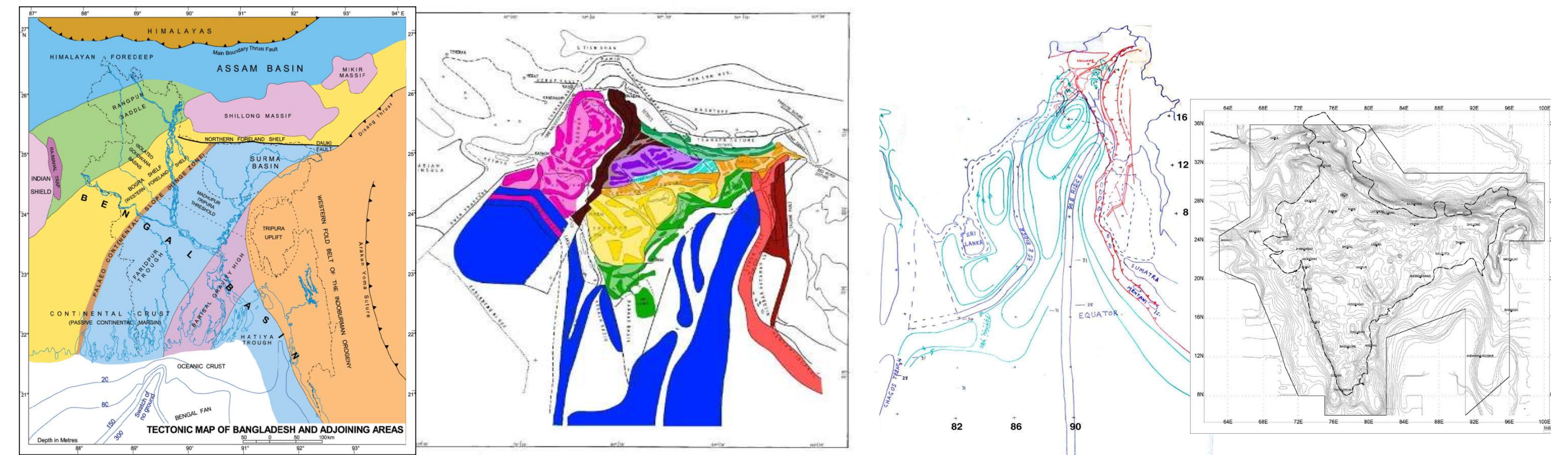

Impact of gravity and other geophysical data on the geology of Indian subcontinent.

T.S. Balakrishnan, Sneh Sadan, Matunga, Mumbai, India, 2003. Journal of the Virtual Explorer 12, 83-92. 


\section{THE CHALLENGE IS TO ASCERTAIN THE RISK LEVEL AND ENGINEERING GEOLOGICAL CHARACTERIZATION FOR SAFE AND SUSTAINABLE DESIGN OF INFRASTRUCTURES}

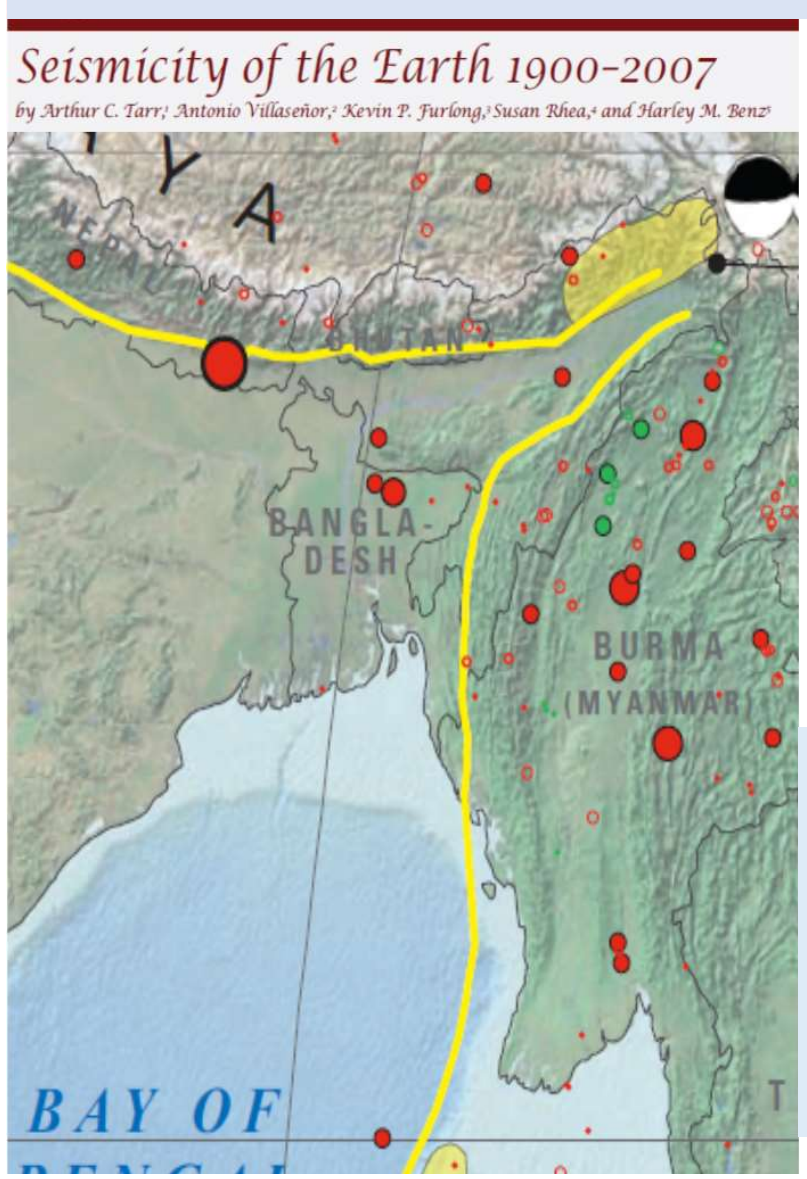

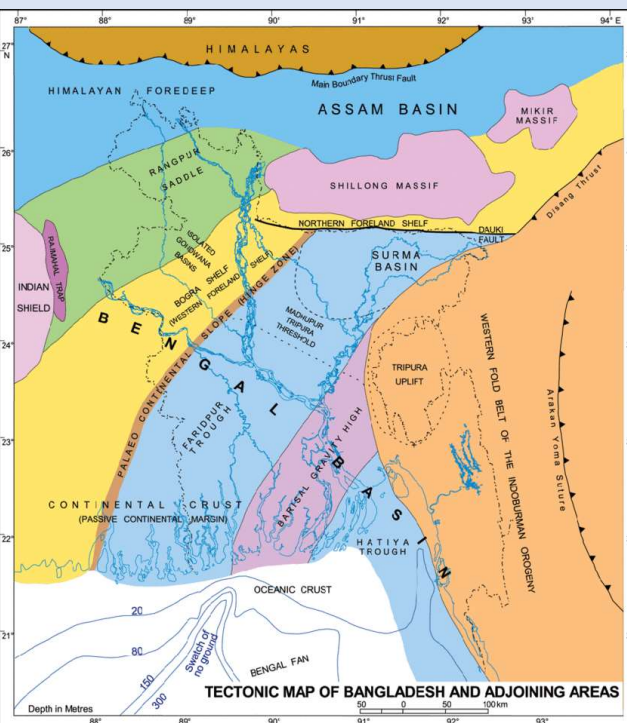

The Geological Survey of Bangladesh prepared tectonic map of Bangladesh in eighties and requires to be updated following new findings and hypotheses for ultimate seismic resilience of urban growth.

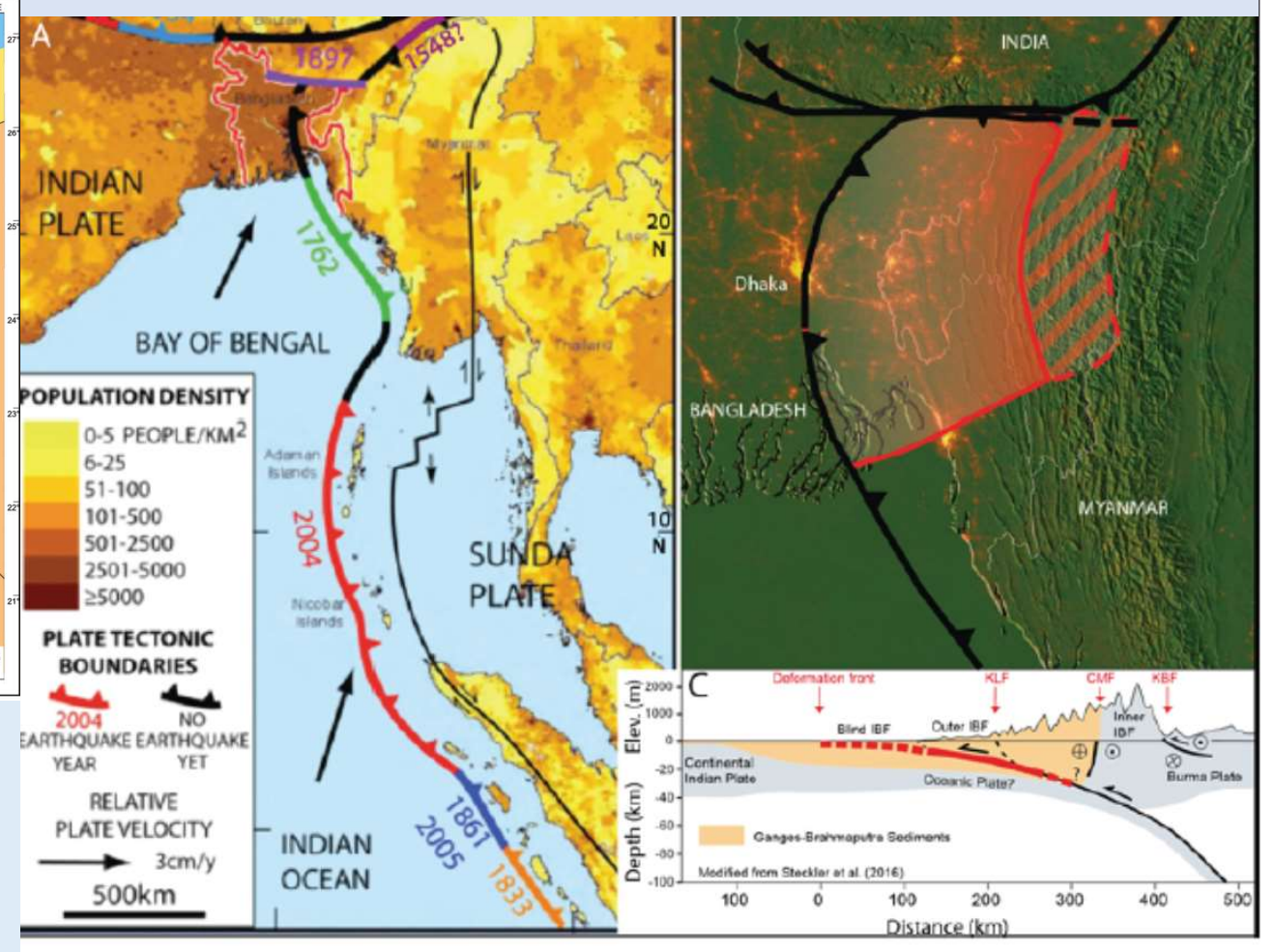

Fig. 1. (a) Major tectonic boundaries of the northeast Indian plate. Numbers represent the years for Ref : Michael S. Steckler, S. Humayun Akhter, Leonardo Seeber 2016 
Real vs the speculated risk. What the society will judge for a sustainable development from the findings of the geologists? 
With rapid growth, demands on infrastructure have driven the need for better understanding of geotechnical exploration and geologic factors that will

contribute to a more manageable, livable, resilient and sustainable infrastructure.

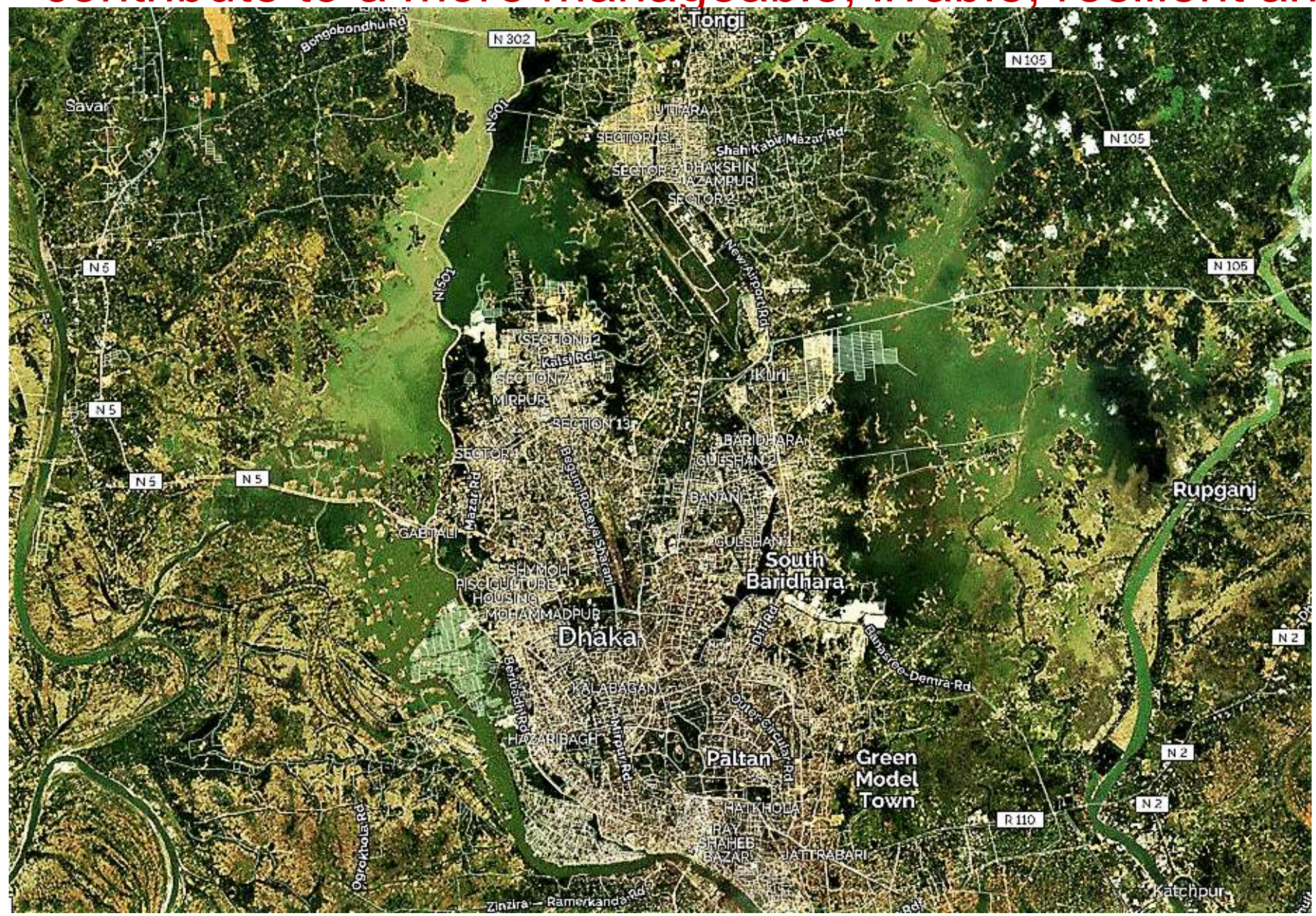

\section{IS MEGA CITY A BIG CLUSTER OF MEGA- RISK?!!}

Image shows dense urban settlement and geomorphological constraints in lateral expansion of the city. The neighboring unused geomorphic segments can pose various geodynamic hazards. Compliance of building code is necessity for engineering geological risk reduction. 
THE MISSING DIALECT

AMONG PRACTICING GEOLOGISTS, ENGINEERS, POLICY MAKER AND SOCIETY.

Need to articulate or formulate a realist compliance system.

Should introduce acceptable testing and probing system 
- The relationship of geo-hazards, geotechnical exploration methods and engineering geologic practices will be discussed.

- The study indicates that geotechnical exploration method, reporting and laboratory testing practices in current use have yet to adopt standard and quality control techniques.
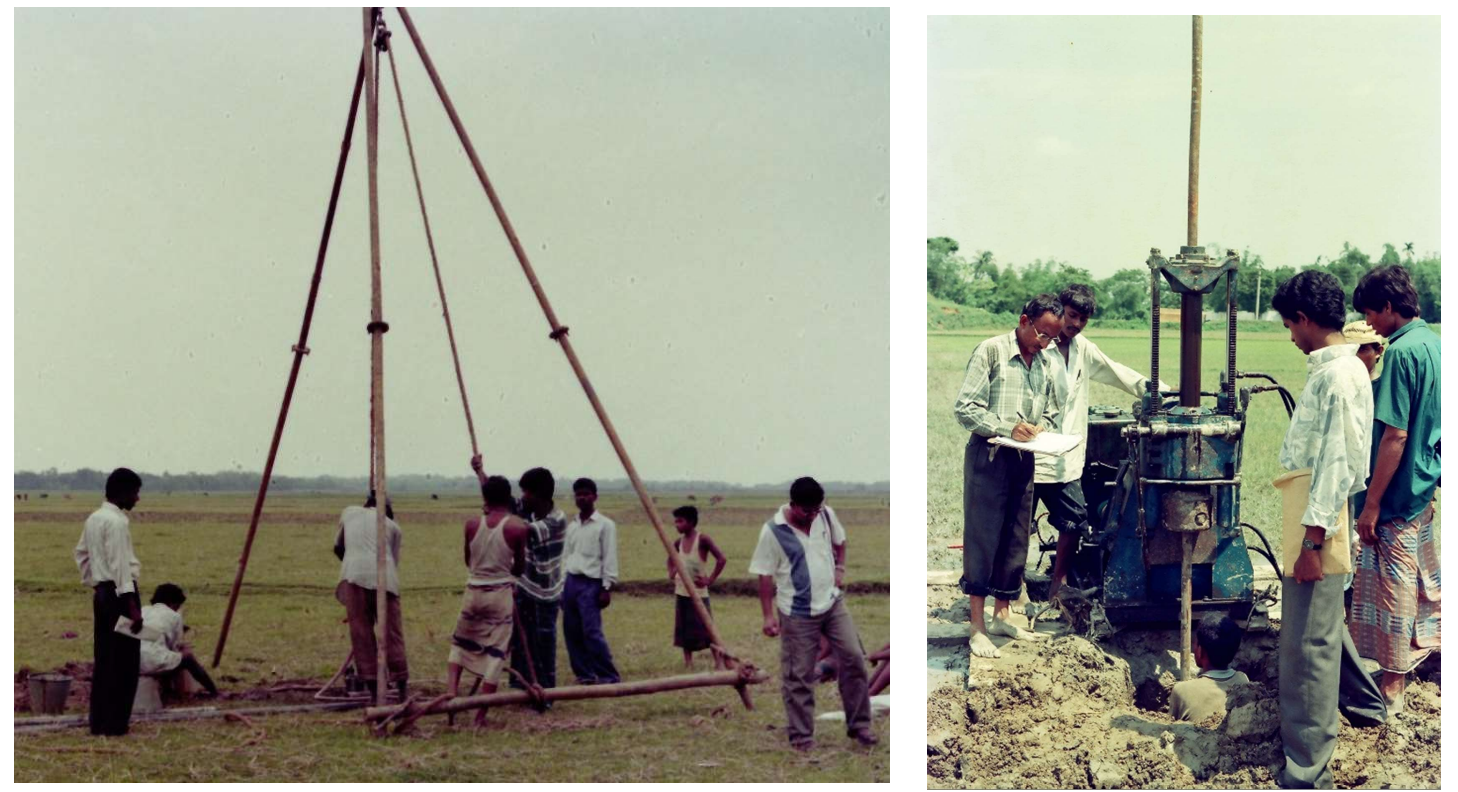

Geotechnical exploration by percussion drilling, while SPT is done manually and cone penetration testing in a remote part of Bangladesh

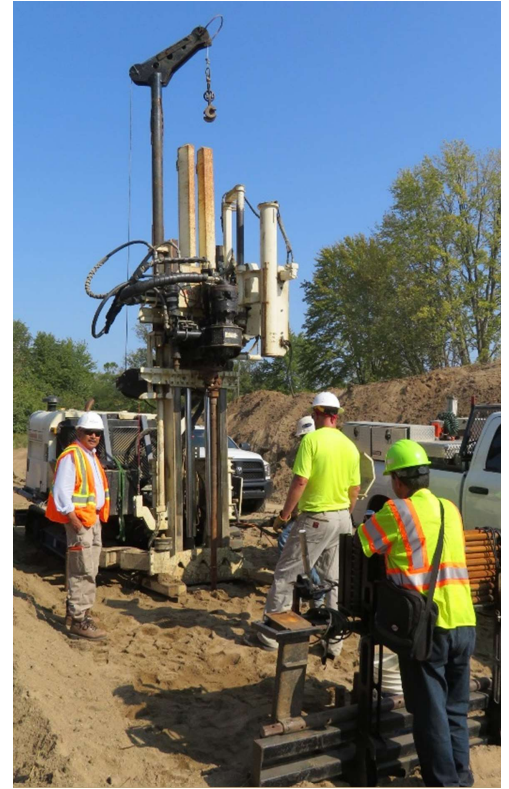

Geotechnical exploration by Geoprobe drilling and cone penetration testing in Indiana, US 


\section{WHAT STANDARD IS FOLLOWED IN BANGLADESH? WHO CONTROLS THE QUALITY OF TESTING?}

- Practice of geotechnical exploration and testing exists in Bangladesh. The testing organizations owned by private companies, except controlled institutes like BUET and different universities or technical colleges.

- But the testing system is yet to adopt controlled quality, standard, unified and acceptable methods.

- BUET and GSB led to form Bangladesh Society for Geotechnical Engineering in 1993 with an objective to create an standard and reliable practice for testing and exploration in Bangladesh by providing training. 


\section{COST OF TESTING IS A BIG FACTOR IN QUALITY CONTROL}

- Entering into a new urbanization process, the development projects of the Bangladesh received finance / funding from various sources and were monitored by respective agencies with prescribed methodology for execution and implementation. This dilemma of funding and ownership over the projects put the geotechnical exploration and testing system in challenging state.

- The large engineering projects are either funded by WORLD BANK, ADB, USAID, DID, EU, JICA and NGOs where the consultants are designated from respective agency and multi-standard practice made hindrance in development of national standard method, though there is Bangladesh Standard and Testing Institute (BSTI). BSTI has yet to take strong shape towards controlling are auditing engineering or technical services. 


\section{THE WORLD OF STANDARDS}

BANGLADESH HAS BSTI - BANGLADESH STANDARD TESTING INSTITUTE BUT DOES NOT INCLUDE OR MENTION CONTROLLED BY STANDARD GEOLOGICAL AND GEOTECHNICAL METHODS

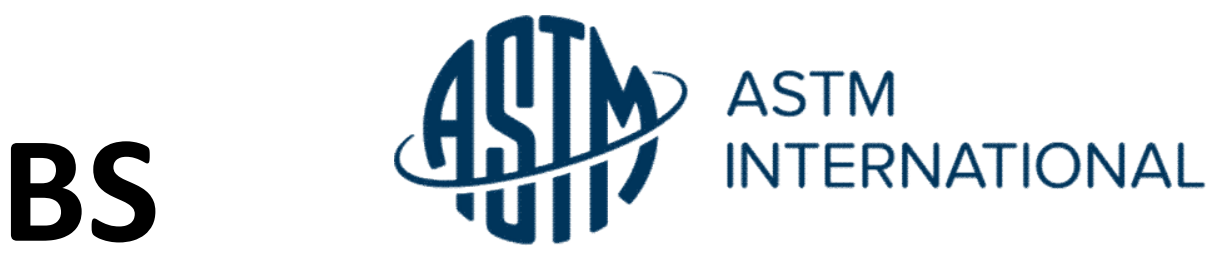

British Standard Methods of Test for Soils for Civil Engineering Purposes

\section{GERMAN}
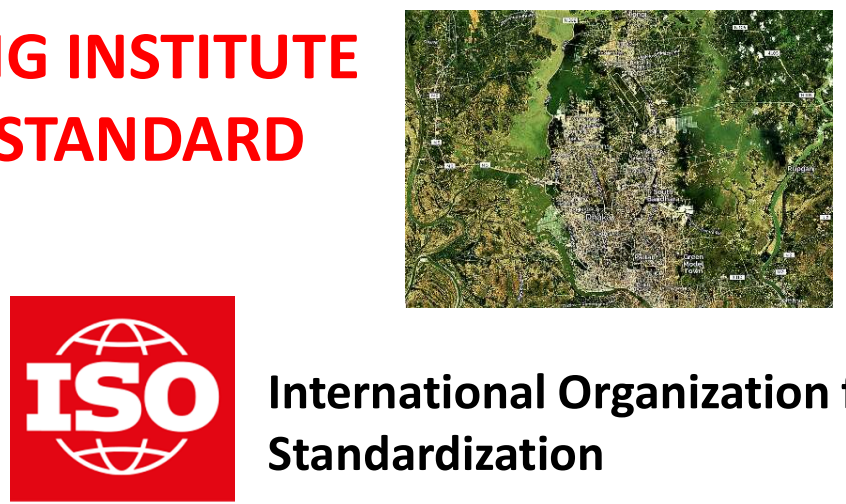

International Organization for Standardization
CODE OF PRACTICE FOR SUBSURFACE INVESTIGATION

LANDWIRTSCHAFLICHE UNTERSUCHUNGS. UND FORSCHUNGSANSTALT SPEYER

The Japanese Geotechnical Society (JGS Standards) /(Laboratory Testing Standards for Geomaterials and Geotechnical and Geoenvironmental Investigation Methods)

\section{CNIS China National Institute of Standardization}



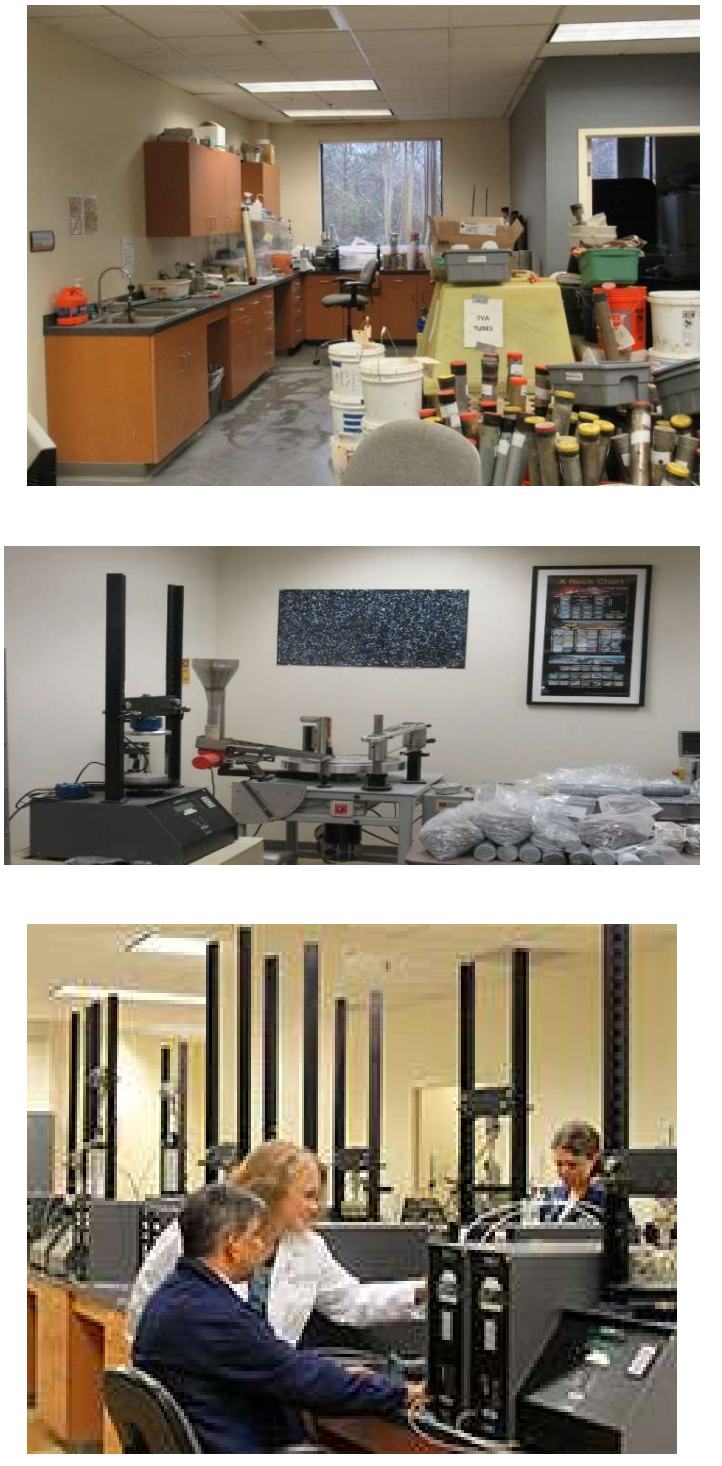

STANDARD, CONTROLLED AND ACCRIDETED LABORATORY TESTING SYSTEM FOR GEOLOGICAL AND GEOTECHNICAL DATA GENRERATION HAVE BECOME AN ESSENTIAL TASK FOR BANGLADESH 
- Engineering geology is concerned with subsurface construction, operation and maintenance for safe and sustainable structures. And need large scale maps.

- Modified large-scale (1:5000) engineering geologic maps are prepared for selected parts of Dhaka to evaluate and integrate the geologic hazards and engineering geologic risk.

STANDARD, CONTROLLED AND ACCRIDETED TESTING SYSTEM WILL GENERATE ACCURATE MAPS AND DOCUMENTS 


\title{
A GEOMORPHOLOGICAL SHIFT
}

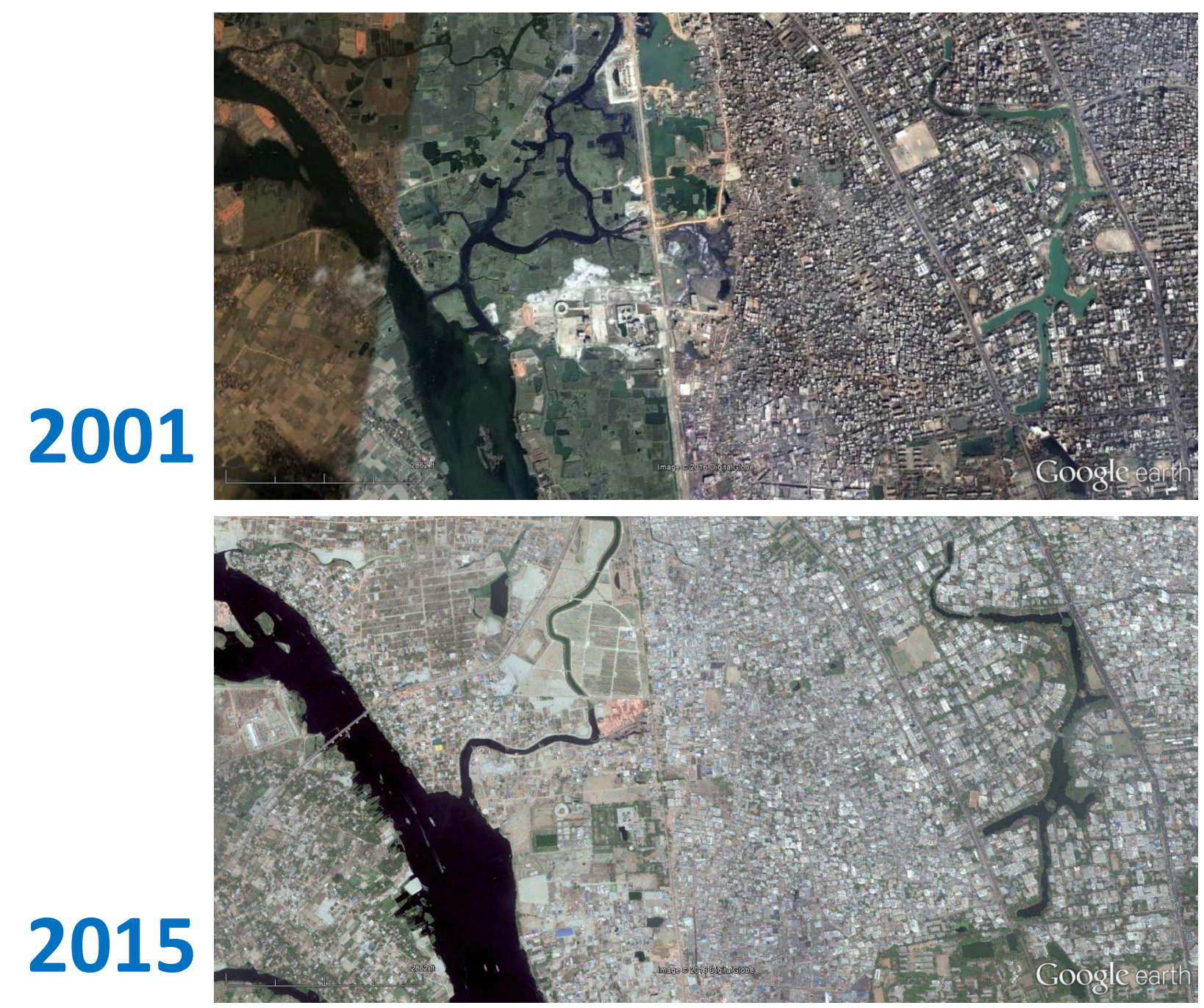

We have created many
environment like Savar
Building Failure which
was simply an
Engineering Geological Failure

\author{
Location Dhaka: \\ $23^{\circ} 44^{\prime} 37.16^{\prime \prime} \mathrm{N}$ \\ $90^{\circ} 21^{\prime} 43.12^{\prime \prime} \mathrm{E}$
}

Geology: Low Floodplain 


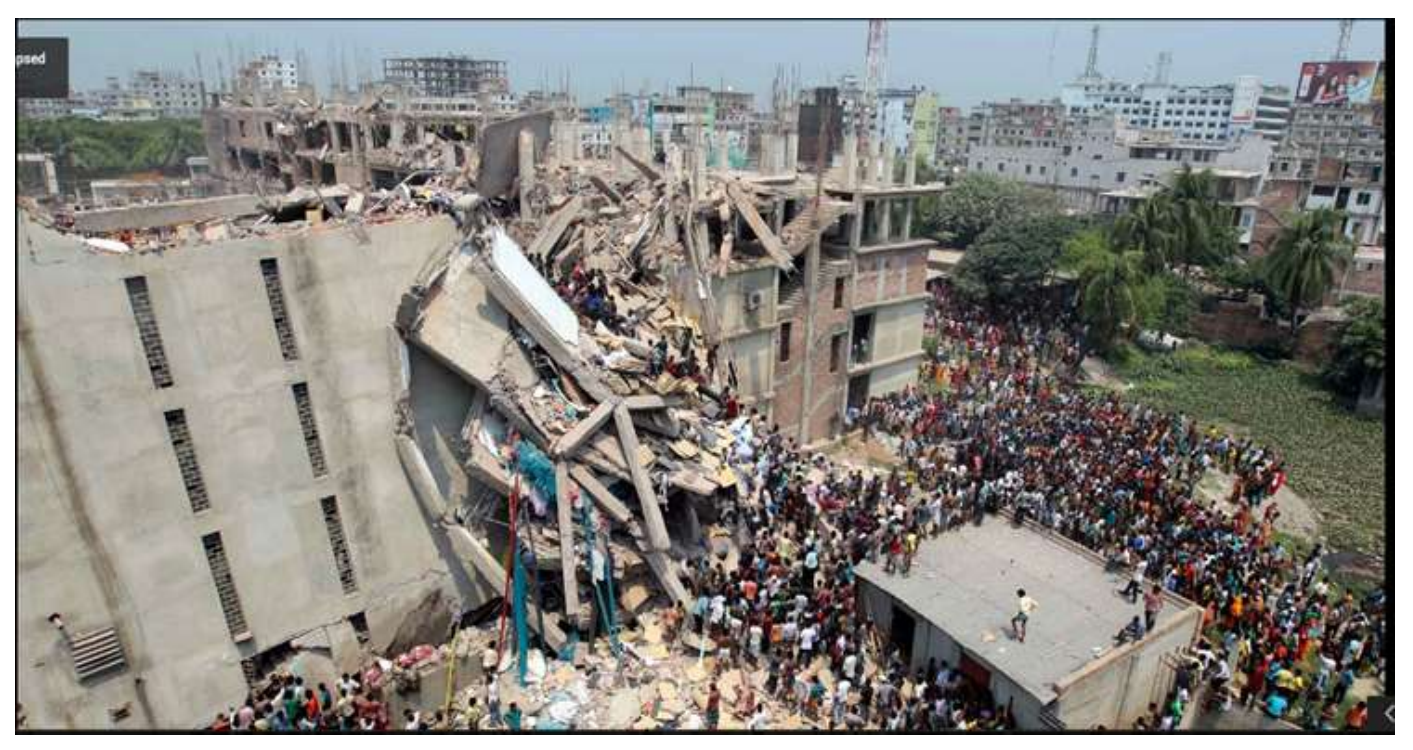

THE COLLAPSE OF A BUILDING, SAVAR AND AN EXAMPLE OF ENGINEERING GEOLOGICAL FAILURE

Bangladesh Industrial Holocaust, 2013: Could this be avoided?

The building occupied a part of a slope of a depression of an abandoned channel, filled up with uncompact soil and municipal waste, raised to the road level from the annual flood level. The building was constructed on 18 inches diameter and $60 \mathrm{ft}$ long bored cast in situ RCC piles where the pile-tips were rested on an abandoned channel fill. The conventional and simple soil investigation would not explain the simple geology and solve the elevation puzzle unless materials are geologically judged. 


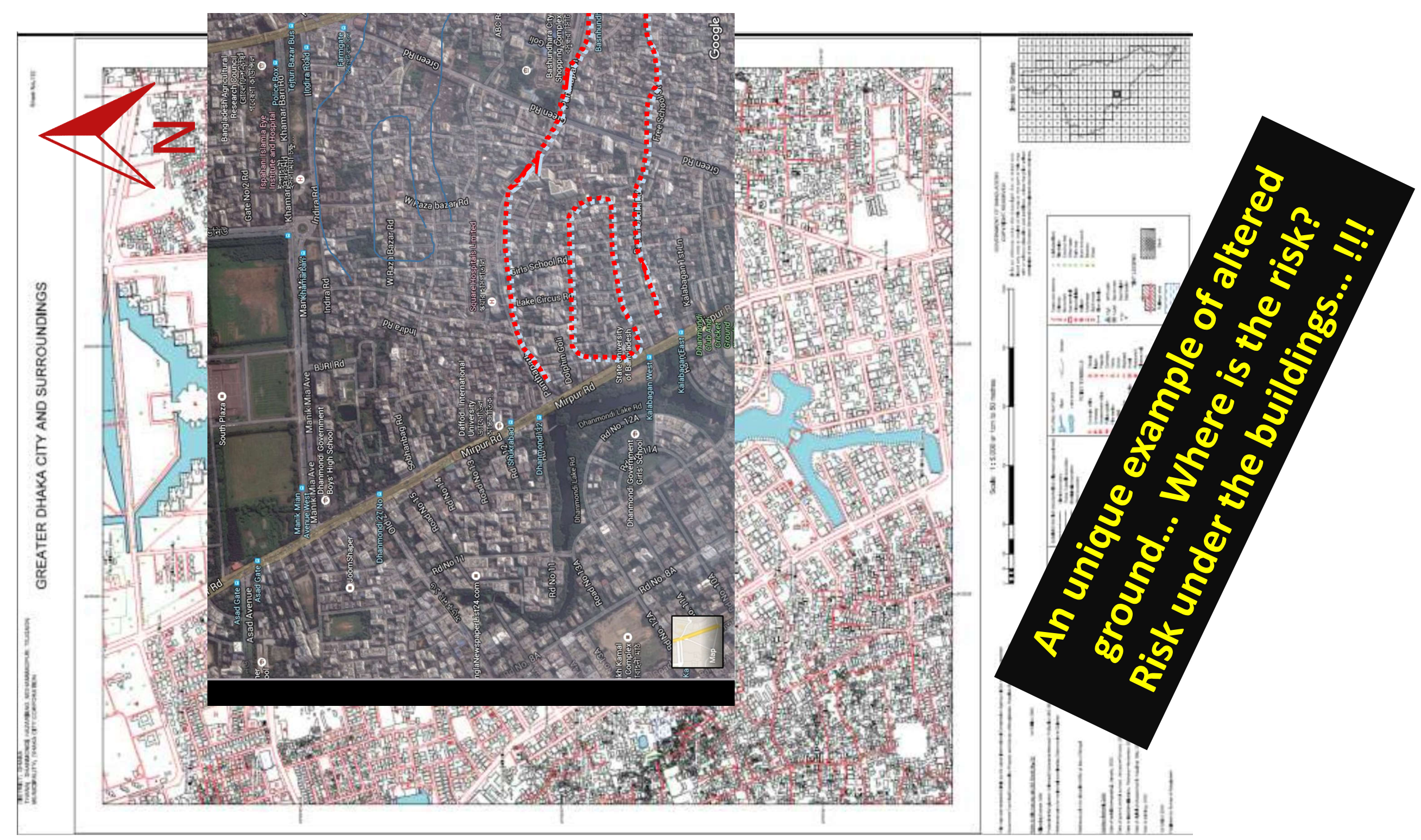




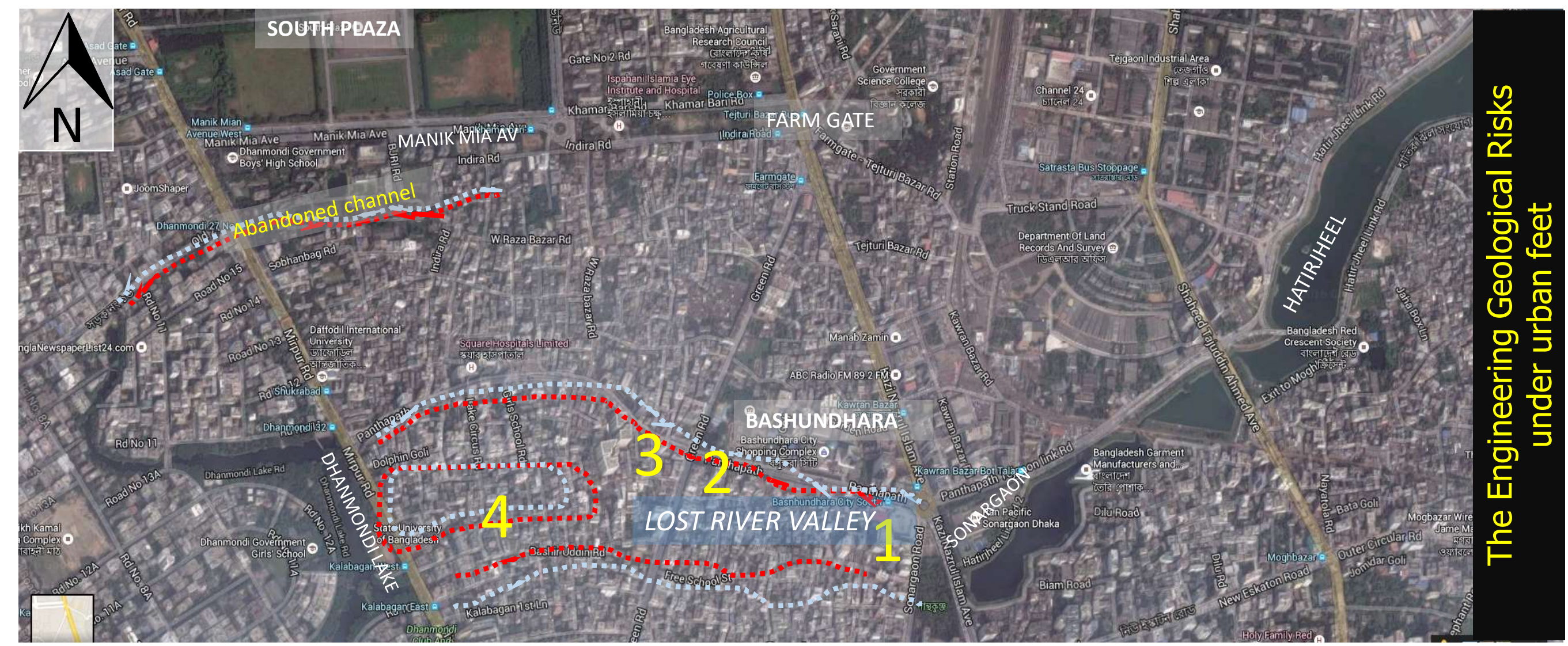

Engineering Geological Risks in the middle of Dhaka City, Bangladesh: The river valleys are lost under the altered ground and urban concrete layers where buildings are collapsed, failed, sinking or living with risks. The locations where recently (1) one under construction high-rise building project failed due to failure of pile construction and site was abandoned, (2) underconstruction building failed and one tilted building still being used where the building was tilted during storm sewer drainage construction, (3) the buildings are still sinking and being used (behind Ferdous Tailors) at Green Rd and Panthapoth crossing and (4) building collapsed in Kolabagan by killing several people. (Investigated by - Mir Fazlul Karim). 
- Risk is always present in any alteration of geologic environment during and after construction.

- Although the underlying thick hard clay and very dense sand in Dhaka provide advantageous ground condition comparing to other cities of the world, the country is confronting difficult geo-engineering challenges for sustainable development and needs to have standardized geotechnical exploration methods, updated geologic maps and improved laboratory testing system to accurately characterize geologic materials for modeling to meet challenges of sustainable development and risk reduction. 


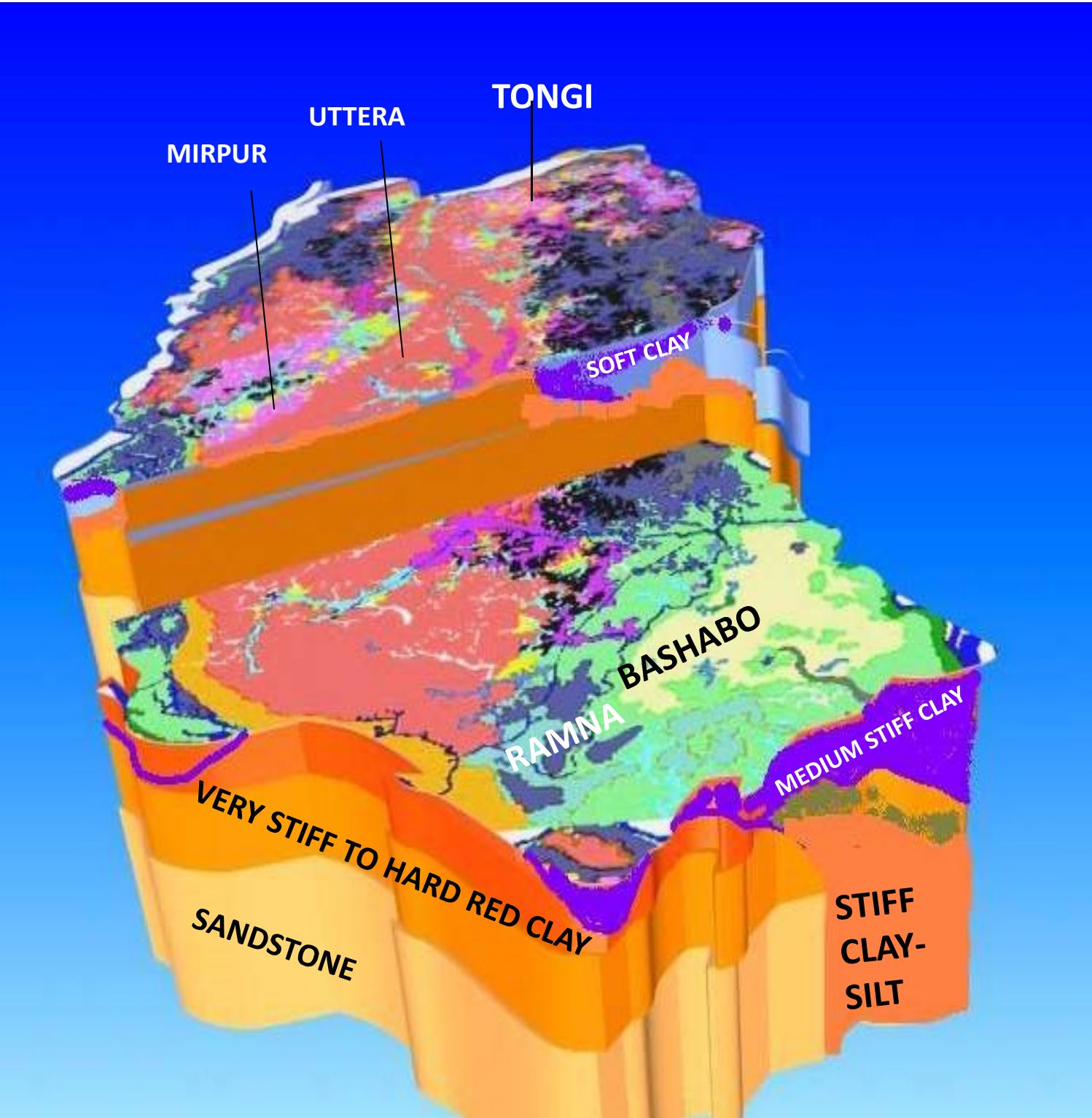

Because of unplanned urban expansion, many cities of Bangladesh will require intense modification to the exiting infrastructures including effective utilization of underground space and construction of multilevel transportation system .

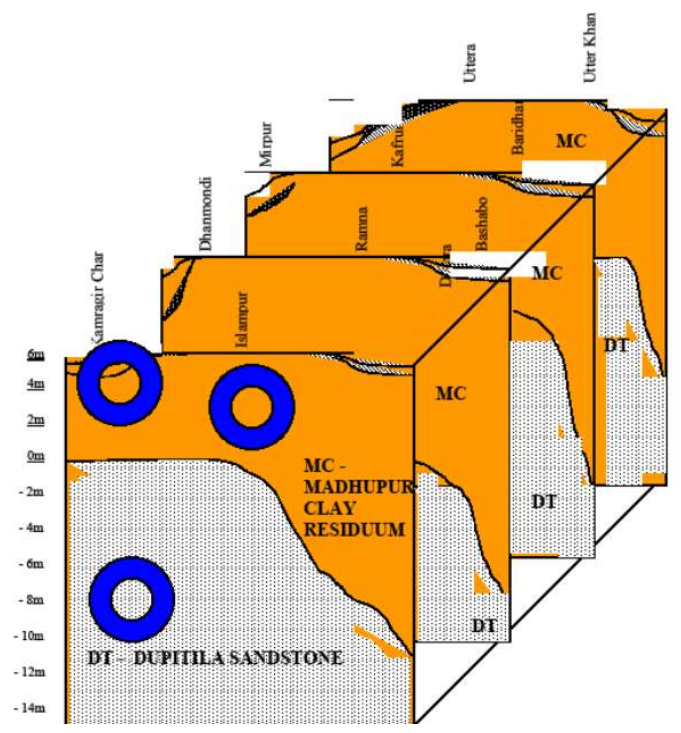

3D Subsurface geological model of Dhaka city, Bangladesh showing surface morphology and two thick top layers of very stiff to hard clay and moderately lithified sandstone; geologically advantageous strata for construction of underground structures. (CAD by Karim, M. F. 2005) 


\section{Furious riverbank erosion, August - September 2018}
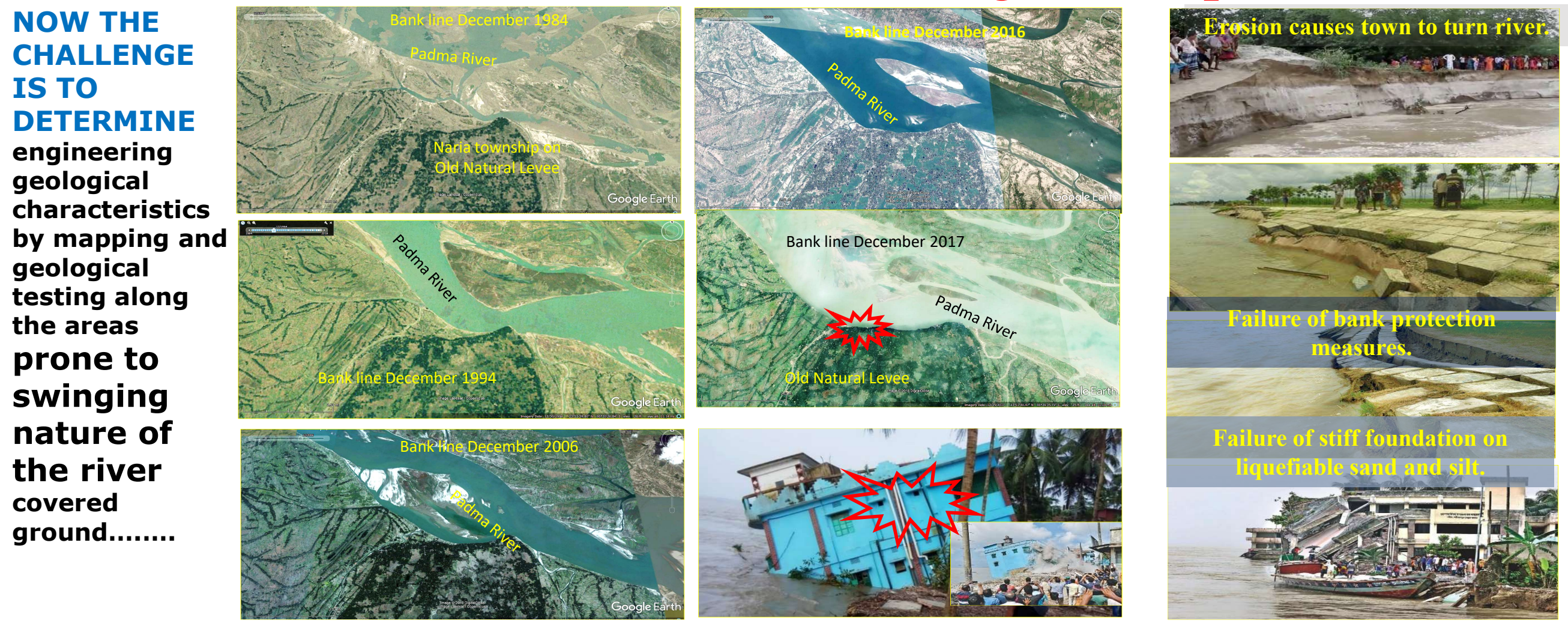

This year the river Padma was severely furious in her flow and bank erosion and caused severe bank erosion and caused demolishing of hundreds of infrastructures, many villages and number of urban centers like Naria Municipality in Shariatpur. During the last months of September and August., 2018 more than 4,000 families have lost their homes. 
- The mighty river Padma is a complex flow of various pattern, ranging between meandering and swiftly shifting braided at different seasons of the year which is totally dependent on discharge and runoff in the Padma River watershed including human interferences and control along the upstream.

- The concerned geological institutes and geotechnical engineering group need to come forward for a detailed geological mapping, scientific investigation and geotechnical analysis of this furious failure. The failure analysis like Naria are not studied or described in American or European text books.

- Present authors speculate similar behavior of the river in the coming years due to global climatic shift and intense human interference along the upstream. 
THE CHALLENGES REMAIN

FOR BANGLADESH FOR QUALITY

and UPDATED LARGE SCALE

DIGITAL-INTERACTIVE

DERIVATIVE MAPS 


\section{YOU ARE INVITED}

TO BOOTH 101
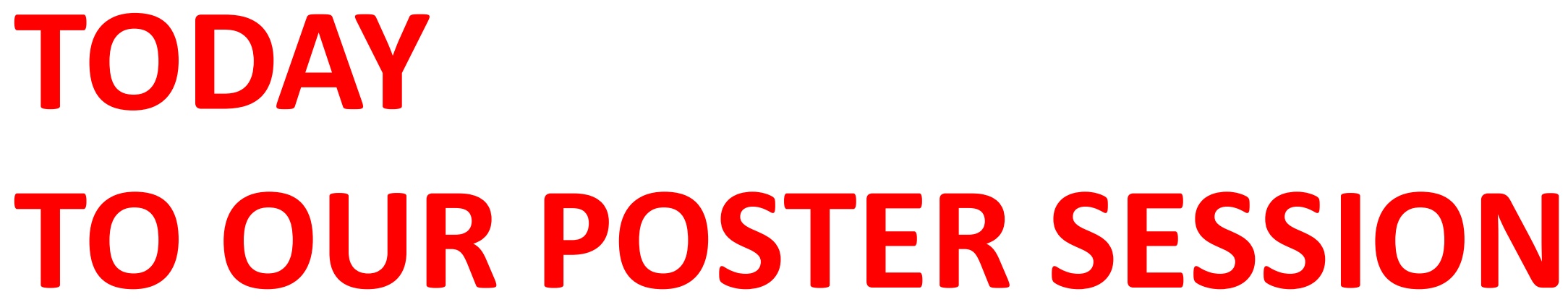

Presentation Time: 9:00 AM-5:30 PM

THE STATUS OF ENGINEERING GEOLOGY: CONSTRAINTS ON INFRASTRUCTURE DEVELOPMENT IN BANGLADESH

Session No. 30--Booth\# 101 T71. Recruiting and Retaining K9-16 Students through Field- and Laboratory -Based Geoscience Experiences (Posters) Sunday, 4 November 2018: 9:00 AM-5:30 PM 
The Status of Engineering Geology: Constraints on Infrastructure Development in Bangladesh Mir Fazlul Karim ${ }^{1}$, Muhammad Qumrul Hassan ${ }^{2}$, Nazrul Islam Khandaker ${ }^{3}$, Masud Ahmed ${ }^{4}$ and Belal Ahmed Sayeed ${ }^{6}$ (1) Engineering Geologist, GeoTesting Express Inc., Geocomp Corporation, Acton, MA 01720, USA (2) Department of Geology, University of Dhaka, Ramna, Dhaka, 1000, Bangladesh

(3) Geology Discipline, Earth and Physical Sciences, York College Of CUNY, 94-20, Guy R. Brewer Blvd, Jamaica, NY 11451, USA (4) New York City Department of Environmental Protection, Geotechnical Section, NYCDEP, 59-17, Junction Blvd, Queens, New York, NY 11373, US (5) Dewberry Geotechnical Company. 132 W 31 st St \#301, New York, NY 10001, USA

\section{GSA 20IR}

4-7 November

Indianapolis, Indiana, USA

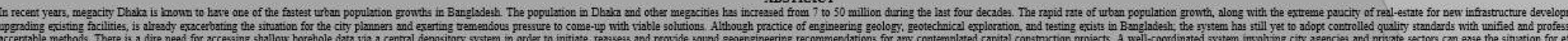

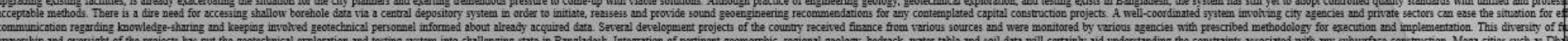

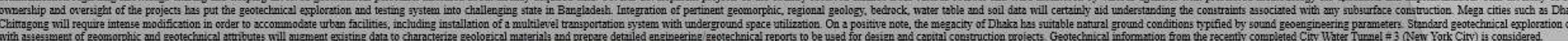

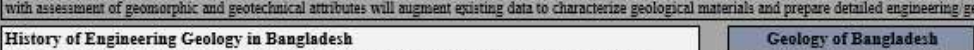

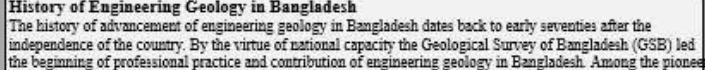

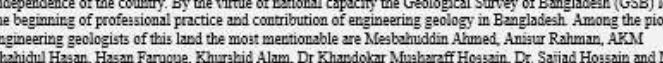

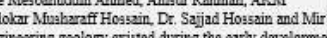

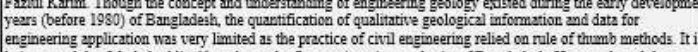

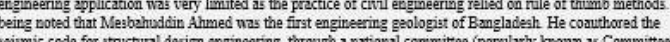

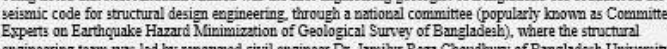

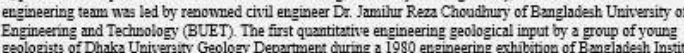

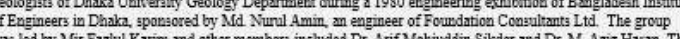

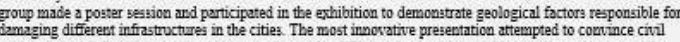

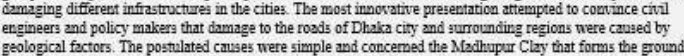

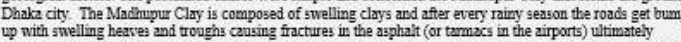

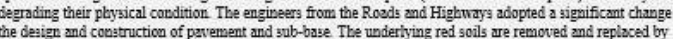

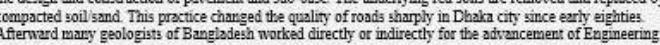

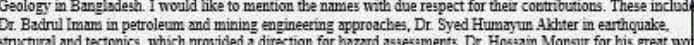

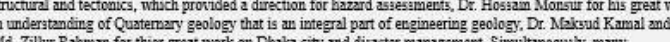

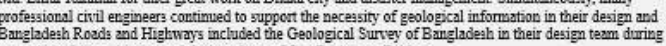

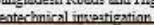

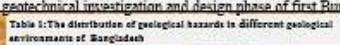

$\Longrightarrow= \pm-m-m$

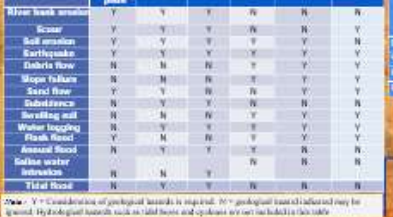

Environmental
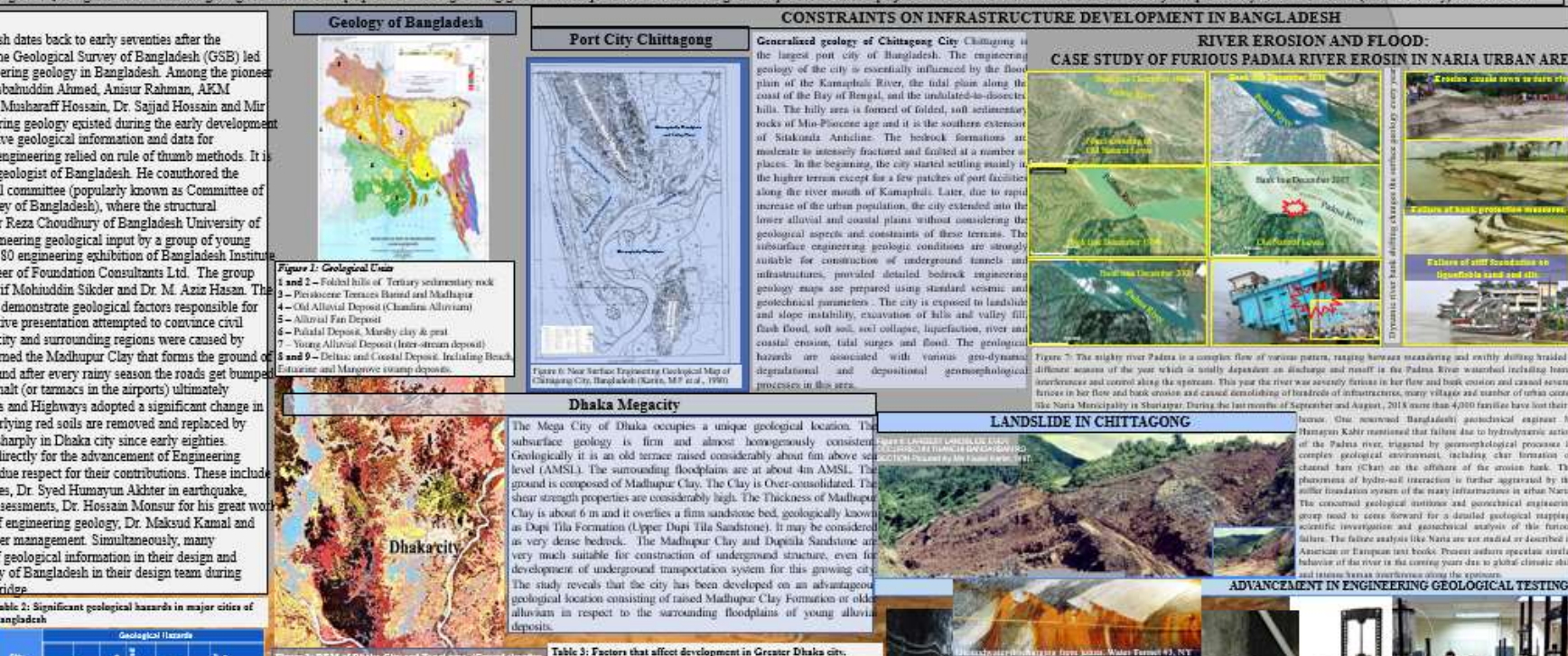

\section{Dhaka Megacity}
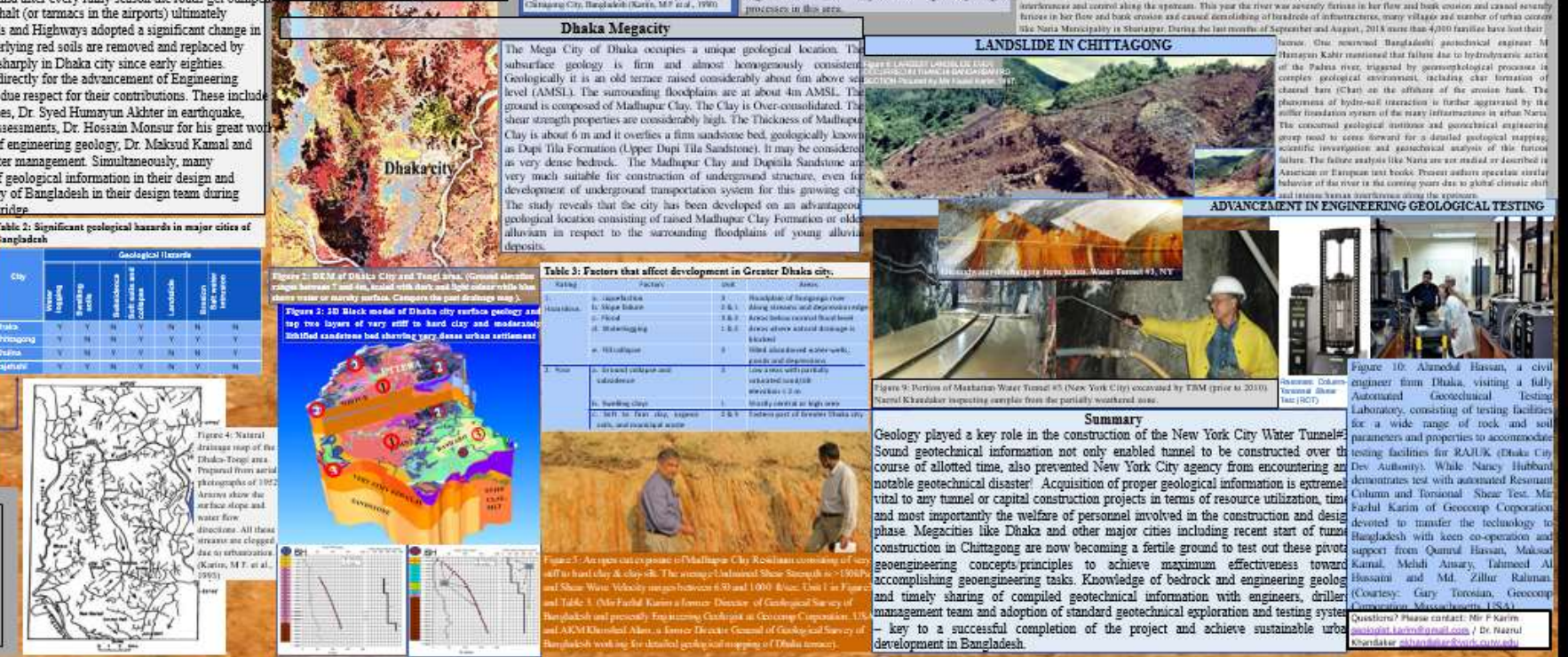

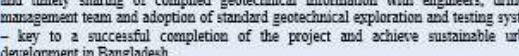


GSA 2 RTR

4-7 November

Indianapolis, Indiana, USA
THANK YOU

FOR

YOUR KIND PATIENCE

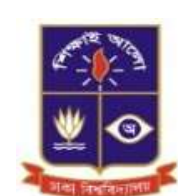

GeoTesting

EX P R E S S 